\title{
The Age Dependent Activities of Digestive Enzymes in Rasbora, Rasbora lateristriata Blkr., (Pisces: Cyprinidae)
}

\author{
Untung Susilo $^{1^{*}}$, Purnama Sukardi ${ }^{2}$, Ridwan Affandi ${ }^{3}$ \\ ${ }^{1}$ Faculty of Biology, Jenderal Soedirman University, Purwokerto, Indonesia. \\ ${ }^{2}$ Faculty of Fisheries and Marine Science, Jenderal Soedirman University, Purwokerto, Indonesia. \\ ${ }^{3}$ Faculty of Fisheries and Marine Science, Bogor Agricultural University, Bogor, Indonesia. \\ *email: susilo.utg@gmail.com; untung.susilo@unsoed.ac.id
}

Received February 8, 2018; Accepted March 29, 2018; Available online May 31, 2018

\begin{abstract}
This study was to evaluate the digestive enzyme activity included a protease (trypsin \& chymotrypsin), lipase, carbohydrase (amylase \& cellulose) and alkaline phosphatase in Rasbora. This research was carried out using three different ages (2, 4 and 6 months) and in each age consisted of six groups (replicates). In this study 150 fish ( \pm 2 months age), 120 fish $( \pm 4$ months age) and 90 fish ( \pm 6 months age) were used. All digestion enzyme activity was measured by the spectrophotometric method, except the lipase activity was by the titration method. The results showed that the distinctness of age resulted in a significant difference on total protease, trypsin, lipase, cellulase and alkaline phosphatase ( $\mathrm{P}<0.05)$, but no significant difference in amylase activity $(\mathrm{P}>0.05)$. Total protease and trypsin activities were higher in fish of age two months than fish age four and six months, but the activity of lipase, cellulase and alkaline phosphatase were higher in fish age of four months compared to two months age fish. Fish, with distinct age has the different nutrient digestion capacity as expressed by differences in the activity of the enzyme digestion, except amylase. These results contribute to the future development of digestive physiology, especially in Rasbora.
\end{abstract}

Keywords: alkaline phosphatase, carbohydrase, lipase, protease, Rasbora

\section{INTRODUCTION}

The ability of fish to digest the feed is highly dependent on the activity of digestive enzymes, such as protease, lipase, carbohydrase, and alkaline phosphatase. Acid protease or pepsin is particularly active in the fish with stomach, as observed in Mormyrus Rume (Odedeyi \& Fagbenro, 2010), Etroplus suratensis and Oreochromis mossambicus (Sankar et al., 2014), but not in fish without stomach (Day, German \& Tibbetts, 2011a) and the Mediterranean fish (Caruso, Denaro, \& Genovese, 2009).

The activities of alkaline protease such as trypsin and chymotrypsin, have also been studied in a variety of fish (Kamarudin, Otoi, \& Saad, 2011; Savona, Tramati, \& Mazzola, 2011). These enzymes showed different activities in the fish digestive tract, according to feed quality (Debnath et al., 2007; Chaudhuri, Mukherjee, \& Homechaudhuri, 2012; Abdel-Warith, Younis, \& Abdualla, 2013), feeding guilds (Falcon-Hidalgo, Forrellat-Barrios, Farnes, \& Hernandez, 2011; Langeland, Lindberg, \& Lund, 2013), phylogeny (German, Horn, \& Gawlicka, 2004; Kumar et al., 2007), and sex (Thongprajukaew \& Kovitvadhi, 2013).
Lipase and carbohydrase activities are varied among fish with different feeding guilds in which omnivorous fish show a lower lipase activity than carnivores (Langeland et al., 2013). Amylase activity is generally higher in herbivorous fish than in omnivores and carnivores (Day et al., 2011b). The ability of fish to digest cellulose is highly dependent on the presence of microbial symbionts in their digestive tracts (Maity, Kundu, Pramanik, \& Patra, 2011; Ganguly \& Prasad, 2012).

Past studies have shown cellulase activity in Oreochromis niloticus (omnivore), but not in Horabagrus brachysoma (omnivore) and carnivorous Parachanna obscura and Gymnarchus niloticus (Fagbenro et al., 2005; Prasad \& Suneesha, 2013). Alkaline phosphatase activity was also affected by changes in the feed quantity and quality (Liu, Zhang \& Wang, 2010), but studies on Labeo rohita indicated otherwise (Debnath et al., 2007). The effect of age or size of the fish on the digestive enzyme activity has also been documented in previous studies (Klahan, Areechon, Yoonpundh, \& Engkagul, 2009; Thongprajukaew, Kovitvadhi, Engkagul, \& Rungruangsak-Torrissen, 2010; Susilo, Yuwono, Rachmawati, Priyanto, \& Hana, 2015). However, the effect of age on enzyme 
activity changes when diet and feeding guilds differ (Day et al., 2011a; Savona et al., 2011; Pena et al., 2015). In spite of elaborate study on digestive enzyme on various fish species, no published data are available for Rasbora digestive enzyme activities related to its age.

Feed consumed by fish will be used for growth if it has been digested in the gastrointestinal tract of fish. The digestive process of feed involving digestive enzymes such as proteases, lipases and carbohydrases, requires the compatibility between the feed consumed and the capacity of fish digestion, in order to achieve feed efficiency (Caruso et al., 2009). The digestion product by the enzyme is a simple compound and readily absorbed by the fish intestine to support growth. Among the digestion products is a phosphate-bonded compound which is a substrate for alkaline phosphatase, so the hydrolysis product becomes easily absorbed (Ducasse-Cabanot $e t$ al., 2007; Silva et al., 2010). Therefore, a good feed quality supported by its enzyme capacity will be an important factor to support fish growth, otherwise when low feed quality will have an effect on the poor of nutrient intake for fish growth (Thongprajukaew et al., 2011; Santigosa et al., 2011).

Rasbora (Rasbora lateristriata Blkr.) is a wild fish that has the potential to be developed, because it has good taste and high nutritional value. Biological studies of the genus Rasbora have been conducted, but mostly focused on the taxonomy aspects of the fish (Kottelat, Whitten, Kartikasari, \& Wirjoatmodjo, 1993), its length to weight relationships (Muchlisin, Musman, \& Azizah, 2010), fecundity and spawning frequency (Muchlisin, Musman, Fadli, \& Azizah, 2011), natural feed (Sulistiyarto, 2012) and its distribution (Rosadi, Yuli, Setyohadi, \& Bintoro, 2014).

A scientific study related to the digestive physiology of fish will be necessary to support the domestication efforts of Rasbora in the future. Therefore, a research focusing on the digestive capacity associated with digestive physiology as expressed by digestive enzyme activity provides new insight, especially for Rasbora. The objective of this study was to evaluate the digestive enzyme activities of total protease, trypsin, chymotrypsin, lipase, amylase, cellulase and alkaline phosphatase with different age in Rasbora.

\section{EXPERIMENTAL SECTION}

\section{Materials and Instruments}

$\mathrm{N} \alpha$ - $p$-tosyl-L-arginine hydrochoride methyl ester (Sigma-Aldrich, AG), N-benzoylL-tyrosine ethyl ester (Sigma-Aldrich, AG), Sodium acetate (Merck, AG), Folin \& Ciocalteu's phenol reagent (Sigma-Aldrich), Starch (Bio Basic Canada, High Purity), carboxymethylcellulose (Merck, Technical Grade), Tris (hydroxymethyl) aminomethane (Tris) (Sigma-Aldrich, ACS reagent, >99.8\%), hydrochloric acid (Merck, 36.5-38.0\%), 3,5dinitrosalicylic acid (DNS) (Sigma-Aldrich, $>98 \%$ ), $\quad p$-nitrophenyl phosphate ( $p$ NPP; Sigma-Aldrich, AG), $p$-nitrophenol (SigmaAldrich, AG), $\mathrm{NaOH}$ (Sigma-Aldrich, AG), single centrifuge (Eppendorf, $5415 \mathrm{R}$ ), spectrophotometry (Hitachi, U-2900), channel pipette (Serana), waterbath (JEIO-TECH, WB20E).

\section{Experimental Design}

The fish sample (F1) was obtained from Wet Laboratory of Biology Faculty, Unsoed, Purwokerto. Fish with three different age maturity (age 2, 4 and 6 months) were rearing in three difference concrete tanks (125 x 250x50cm) and feed twice days at 08:00-09:00 pm and 15:00-16:00 pm. Fish were fed with artificial diet containing crude protein $33.71 \%$, crude lipid $5.67 \%$ and NFE $38.96 \%$ as a previous study on Rasbora (Susilo, Sukardi \& Affandi, 2016) during two weeks rearing. In this study 150 fish (age \pm 2 months, mean weight $0.28 \pm 0.04 \mathrm{~g}$ ), 120 fish (age \pm 4 months, mean weight $0.44 \pm 0.08 \mathrm{~g}$ ) and 90 fish (aged \pm 6 months, mean weight $0.74 \pm 0.12 \mathrm{~g}$ ) were used. Fish was fasted for $24 \mathrm{~h}$ before the sampling. At the end rearing fish from each concrete tanks divided into six pools sample.

\section{Crude enzyme preparation.}

Using a tissue Homogenizer (Heidolph Dixie 900), the digestive organs were isolated and homogenized $(1: 8 \mathrm{w} / \mathrm{v})$ in a cold solution of $50 \mathrm{mM}$ Tris- $\mathrm{HCl}$ buffer ( $\mathrm{pH}$ 7.5) containing $10 \mathrm{mM} \mathrm{NaCl}$. Homogenates were centrifuged at $12.000 \mathrm{RPM}$ (Eppendorf, $5415 \mathrm{R}$ ) for 15 minutes at $4{ }^{\circ} \mathrm{C}$ and the supernatant was stored in the refrigerator at $-80{ }^{\circ} \mathrm{C}$ (Thongprajukaew et al., 2010) until used for enzyme activity measurements. Soluble protein contents in the supernatant were determined using albumin as a measurement standard. 


\section{Determination of Digestive Enzymes Activity}

A modification of casein hydrolysis was used to measure the activity of total protease (Thongprajukaew et al., 2010). The buffers included glycine- $\mathrm{HCl} 0.1 \mathrm{M}(\mathrm{pH} 2.0)$, citrate $0.1 \mathrm{M}$ (pH 5.0), phosphate $0.1 \mathrm{M}(\mathrm{pH} 6.9)$, Tris- $\mathrm{HCl} 0.1 \mathrm{M}(\mathrm{pH} 8.1)$ and Glycine- $\mathrm{NaOH}$ $0.1 \mathrm{M}(\mathrm{pH} 10.0)$ and $\mathrm{KCl}-\mathrm{NaOH}(\mathrm{pH} 12.5) 0.1$ $\mathrm{M}$. The reaction mixture consisting of casein $1 \%(\mathrm{w} / \mathrm{v})$ in buffer $(450 \mu \mathrm{L})$, buffer $(450 \mu \mathrm{L})$ and crude enzyme extract $(100 \mu \mathrm{L})$ were incubated for $60 \mathrm{~min}$ at $37^{\circ} \mathrm{C}$. This reaction of the mixture was stopped by the addition of $1000 \mu \mathrm{L}$ TCA $8 \%(\mathrm{w} / \mathrm{v})$ reagent.

The same procedure was done to blank tube except that the enzyme extract was added after the TCA $8 \%(\mathrm{w} / \mathrm{v})$. After storing for 1 hour in $4{ }^{\circ} \mathrm{C}$, the sample was centrifuged at $6000 \mathrm{rpm}$ for 10 minutes. The absorbance of supernatant was measured at a wavelength of $280 \mathrm{~nm}$. Protease activity was calculated using a standard curve of tyrosine. The amount of enzyme required to catalyze the formation of 1 $\mu \mathrm{g}$ tyrosine $\min ^{-1}$ was defined as one unit of enzyme activity.

The trypsin activity was measured using No-p-tosyl-L-arginine hydrochloride methyl ester (TAME; Sigma-Aldrich, AG) as substrate (Khishimura, 2008). Reagent mixture consisted of $100 \mu \mathrm{L}$ of enzyme extract and $300 \mu \mathrm{L}$ of 10 $\mathrm{mM}$ TAME in $2600 \mu \mathrm{L}$ of $46.0 \mathrm{mM}$ Tris- $\mathrm{HCl}$ buffer at $\mathrm{pH} 8.1$ with $11.5 \mathrm{mM} \quad \mathrm{CaCl}_{2}$. Reactions were started by adding the enzyme extract into a mixture of TAME and buffer solution. TAME hydrolysis were measured as the change in absorbance at $247 \mathrm{~nm}$ for 3 minutes at $30{ }^{\circ} \mathrm{C}$. Trypsin activity was expressed as the change in absorbance $\min ^{-1}$ $\mathrm{mg}^{-1}$ protein in enzyme extract.

N-benzoyl-L-tyrosine ethyl ester (BTEE;Sigma-Aldrich, AG) was applied as a substrate to measure the activity of chymotrypsin (Lazzari et al., 2010). Reagent mixture consisted of $100 \mu \mathrm{L}$ of enzyme extract and $1400 \mu \mathrm{L}$ of $2.0 \mathrm{mM}$ BTEE in $1500 \mu \mathrm{L}$ of $80.0 \mathrm{mM}$ Tris- $\mathrm{HCl}$ buffer at $\mathrm{pH} 7.8$ with $0.1 \mathrm{M}$ $\mathrm{CaCl}_{2}$. Reactions were started by addition of enzyme extract to the mixture BTEE and buffer solution. BTEE hydrolysis was measured as change absorbance at $256 \mathrm{~nm}$ for 3 minutes at $30{ }^{\circ} \mathrm{C}$. The activity of chymotrypsin was expressed as the change in absorbance $\min ^{-1} \mathrm{mg}^{-1}$ protein in enzyme extract.
Titration method with olive oil emulsion as substrate was used to measure lipase activity (Borlongan, 1990). Reagent mixture consisted of a substrate $(2000 \mu \mathrm{L}), 0.1 \mathrm{M}$ Tris- $\mathrm{HCl}$ buffer at $\mathrm{pH} 8.0(3000 \mu \mathrm{L})$ and extract enzyme $\left(500 \mathrm{~mL}\right.$ ) was incubated for $2 \mathrm{~h}$ at $37{ }^{\circ} \mathrm{C}$, then stopped by the addition of $3000 \mu \mathrm{L}$ ethyl alcohol $95 \%(\mathrm{v} / \mathrm{v})$. The reaction mixture was titrated with $0.01 \mathrm{~N} \mathrm{NaOH}$ using $0.9 \%$ (w/v) phenopthalien in ethanol as indicator. The same procedure was conducted to blank tube except enzyme extract was added after ethyl alcohol and immediately before titration. Lipase activity expressed as units of activity per $\mathrm{mg}$ protein. Lipase activity unit (U) was defined as the volume of $0.01 \mathrm{~N} \mathrm{NaOH}$ required to neutralize the fatty acid released during the 2 hours of incubation of the substrate and after correction by the blank sample.

A standard protocol of 3,5-dinitrosalicylic acid (Sigma-Aldrich, AG) using starch as substrate was used to measure amylase activity (Klahan et al., 2009), whereas phosphate $0.1 \mathrm{M}(\mathrm{pH} \mathrm{6.9)}$ and Tris- $\mathrm{HCl} 0.1 \mathrm{M}$ $(\mathrm{pH} 8.1)$ reagents were used as the buffer. A Reagent mixture which consisted of a substrate $(750 \mu \mathrm{L})$, buffer $(700 \mu \mathrm{L})$ and extract the enzyme $(50 \mu \mathrm{L})$ was incubated for $20 \mathrm{~min}$ at $37{ }^{\circ} \mathrm{C}$ and the reaction was stopped by the addition of $1500 \mu \mathrm{L}$ DNS $1 \%(\mathrm{w} / \mathrm{v})$. The reaction mixture was placed in boiling water for 5 minutes.

The same procedure was conducted to blank tube, except enzyme extract was added after the DNS $1 \%(\mathrm{w} / \mathrm{v})$. The absorbance of the reaction mixture was measured at $540 \mathrm{~nm}$, after previously added $3000 \mu \mathrm{L}$ of doubly distilled water. The amount of maltose removed from substrate was determined from a standard curve of maltose. Amylase activity was calculated as the amount of maltose released $(\mu \mathrm{mol}) \mathrm{min}^{-1} \mathrm{mg}^{-1}$ protein in enzyme extract.

Measurement cellulose activity used 3,5Dinitrosalicylic acid (Sigma-Aldrich, AG) method with carboxymethylcellulose (CMC) as substrate (Savona et al., 2011). Reagent mixture consisted of a substrate $(300 \mu \mathrm{L}), 0.1$ $\mathrm{M}$ sodium acetate buffer $(300 \mu \mathrm{L})$ and enzyme extract $(60 \mu \mathrm{L})$ were incubated for 10 minutes at $40{ }^{\circ} \mathrm{C}$ then the reaction was stopped by the addition of $900 \mu \mathrm{L}$ of DNS $1 \%$ (w/v) reagent. The reaction mixture was placed in boiling water for 15 minutes. The same procedure was 
done at blank tube, except enzyme extract was added after the DNS $1 \%$ reagent. The absorbance of the reaction mixture was measured at $640 \mathrm{~nm}$, after previously added $3000 \mu \mathrm{L}$ of doubly distilled water. The amount of glucose released from substrate was determined from the glucose standard curve. Cellulose activity was calculated as the amount of glucose released $(\mu \mathrm{mol}) \mathrm{min}^{-1} \mathrm{mg}^{-1}$ protein in enzyme extract.

A modified method using $p$-nitrophenyl phosphate ( $p$ NPP; Sigma-Aldrich, AG) as the substrate was used to measure alkaline phosphatase activity (Debnath et al., 2007). The reaction mixture consisted of $1000 \mu \mathrm{L}$ of substrate buffer (0.1 M Glycine, $\mathrm{pH} 10.4 ; 3$ $\mathrm{mM}$ p-nitrophenyl phosphate in $1 \mathrm{mM} \mathrm{MgCl}_{2}$ ) and the enzyme extract $(50 \mu \mathrm{L})$ were incubated for 30 minutes at $30{ }^{\circ} \mathrm{C}$, then the reaction was stopped by the addition of $1500 \mu \mathrm{L}$ of $3.0 \mathrm{~N}$ $\mathrm{NaOH}$. The same procedure was conducted to blank tube, except enzyme extract was added after of $3.0 \mathrm{~N} \mathrm{NaOH}$. The product of hydrolysis of $p$-nitrophenyl phosphate (pNPP) was measured at $405 \mathrm{~nm}$. Alkaline phosphatase activity was determined from a standard curve of $p$-nitrophenol. Alkaline phosphatase activity was expressed in $\mathrm{U}$ ( $\mu \mathrm{g} \quad p$-nitrophenol liberated) $\mathrm{mg}^{-1}$ protein in enzyme extract.

\section{Statistical Analysis}

Enzyme activity values were tested by analysis of variance (ANOVA), followed by Tukey's multiple comparison tests. Statistical analysis was performed using SPSS 18.0 package version of Windows software.

\section{RESULTS AND DISCUSSION}

There were significant differences of total protease activity between the age of the fish ( $p$ $<.05)$ and the high protease activity was found

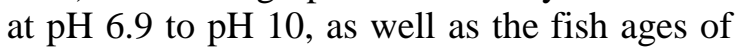
two months have the highest protease activity (Table 1).

In this study, the total protease activity was not found at $\mathrm{pH} 1.9$ and it showed a low at $\mathrm{pH}$ 5.1. This phenomenon indicated that there was no pepsin-like activity that was active at acidic $\mathrm{pH}$. These results were different from previous studies on Betta splendens (Tongprajukaew et al., 2010), Tilapia rendali (Hlophe \& Moyo, 2013) and Horabagrus brachysoma (Prasad \& Suneesha 2013) and Etropus suratensis and Oreochromis mossambicus (Sankar et al., 2014).

Tabel 1. The total protease activity of Rasbora at different ages and $\mathrm{pH}$ activity

\begin{tabular}{ccccccc}
\hline \multirow{2}{*}{$\begin{array}{c}\text { Age of } \\
\text { fish } \\
\text { (months) }\end{array}$} & 1.9 & 5.1 & 6.9 & 8.1 & 10 & 12.5 \\
\cline { 2 - 7 } $2(\mathrm{n}=6)$ & - & $9.15 \pm 1.52 \mathrm{a}$ & $127.56 \pm 26.11 \mathrm{a}$ & $140.48 \pm 39.29 \mathrm{a}$ & $131.81 \pm 42.00 \mathrm{a}$ & - \\
$4(\mathrm{n}=6)$ & - & $2.94 \pm 1.59 \mathrm{~b}$ & $91.92 \pm 24.02 \mathrm{~b}$ & $100.33 \pm 35.10 \mathrm{ab}$ & $90.06 \pm 26.14 \mathrm{ab}$ & - \\
$6(\mathrm{n}=6)$ & - & $3.52 \pm 2.98 \mathrm{~b}$ & $80.21 \pm 13.86 \mathrm{~b}$ & $75.41 \pm 10.53 \mathrm{~b}$ & $69.26 \pm 26.02 \mathrm{~b}$ & - \\
\hline
\end{tabular}

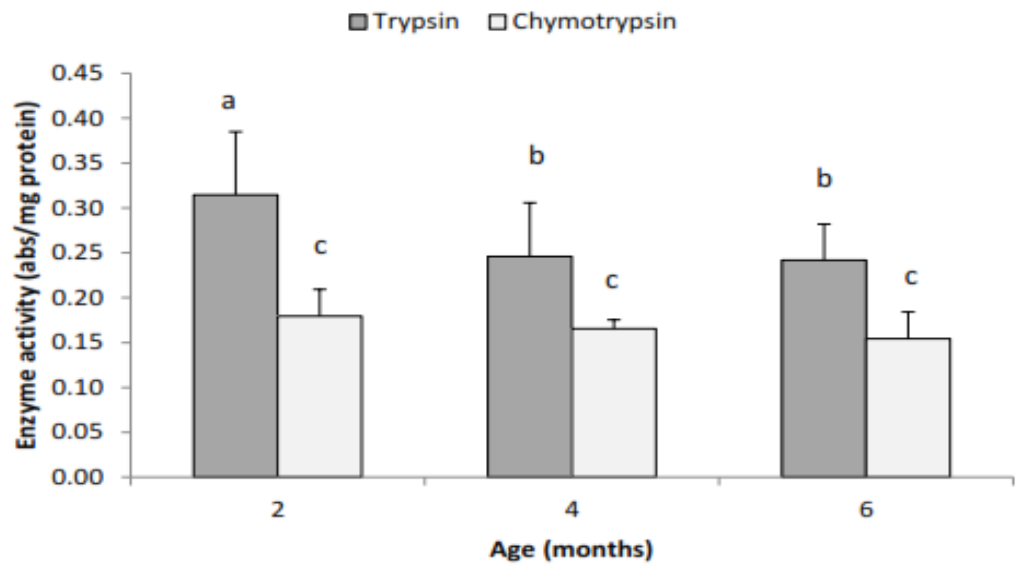

Figure 1. Trypsin and chymotrypsin activities in Rasbora at different age. Means (+sd) with different superscript letter are significantly different $(\mathrm{P}<.05 ; \mathrm{n}=5)$. 
The existence of the activity of pepsin or pepsin-like seems to be related to the presence of a functional stomach. Rasbora on this research may be included in the category of fish with non functional stomach since there is no pepsin-like activity. This funding has also confirmed with Zenarchopterus buffonis (Abidin et al., 2016). At all the fish ages the total protease activity measured at $\mathrm{pH} 6.9$ to 10.0 showed a high activity indicating that protease digestion of the fish is active at a neutral to alkaline condition which occurred in the segment of intestine.

The results of this study do not differ from previous research on Betta spledens (Thongprajukaew et al., 2010), Odontobutis obscures (Ye, Chen \& Zhu, 2013) and Lutjanus guttatus (Pena et al., 2015). The total protease activity was also found higher in two months old fish than in four and six months old fish, which indicates that young fish have a higher protein digestive capacity than the older. This is in contrast to results of previous studies on fish omnivore Oreochromis niloticus (Klahan et al., 2009) and herbivore Hyporhamphus regularis ardello (Day et al., 2011a) and Eurasian perch, Perca fluviatilis (Langeland et al., 2013). The higher activity of protease in two months old fish than in four and six months old fish may be associated with the higher protein requirements for growth, as was observed in Oreochromis niloticus (Abdel-Tawwab, Ahmad, Kattab \& Halaby, 2010).

Trypsin activity was significantly different among the age or weight of the fish ( $p$ $<.05)$ with the highest trypsin activity found in fish age of two months (Figure 1), but the activity of chymotrypsin was not significantly different among age or weight of the fish ( $p>.05)$. The results of this study did not differ from previous research on Lates niloticus (Namulawa et al., 2013), Horabagrus brachysoma (Prasad \& Suneesha, 2013) and Labeo rohita (Umalatha, Kushwaha \& Gangadhar, 2016), but it is contrary to the results on Limia vittata \& Gambusia punctate (Falcon-Hidalgo et al., 2011) and Hyporhamphus regularis ardelio (Day et al., 2011a).

So it seems that the Rasbora changes in protein digestive capacity, as indicated by the increased activity of total protease, dominated by the activity of trypsin and not by the activity of chymotrypsin. Trypsin activity is higher than chymotrypsin, reflecting the absence of growth inhibition in the fish, and the high activity of trypsin can be an indicator of increased growth and efficiency of feed on fish ( Chan et al., 2008; Rungruangsak-Torrissen et al., 2009).

Lipase activity was found significantly different between the age of the fish $(\mathrm{P}<.05)$, and the lowest activity was found in the fish with two months of age, but the activity of lipase with four and six months of age did not differ between the two (Figure 2). The results of this study were lower than previous studies on Glyptosternum maculatum (Xiong, Xie, Zhang \& Liu, 2010). The incubation time differences in this study were shorter than previous research indicating one cause of the differences in the results of this research. However, the result is consistent with previous research on Oreochromis niloticus (Klahan et al., 2009). Results of previous studies had also shown that the activity of lipase was in the range of neutral to alkaline $\mathrm{pH}$, which indicated that the lipase working on the digestive tract of fish was a lipase secreted by the pancreas or hepatopancreas (ZamboninoInfante \& Cahu, 2007) with the intestine as the main segment of fat digestion $(\mathrm{Wu}$, Hong \& Zhang, 2010).

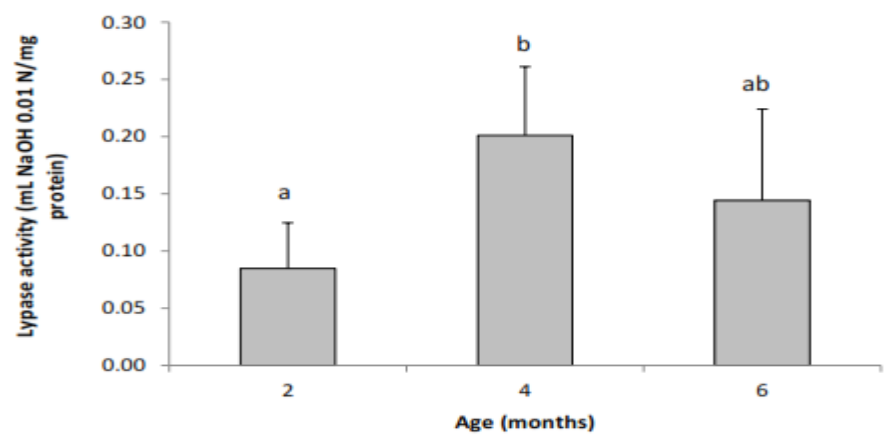

Figure 2. Lypase activity in Rasbora at different age. Means (+sd) with different superscript letter are significantly different $(\mathrm{P}<.05 ; \mathrm{n}=6)$ 


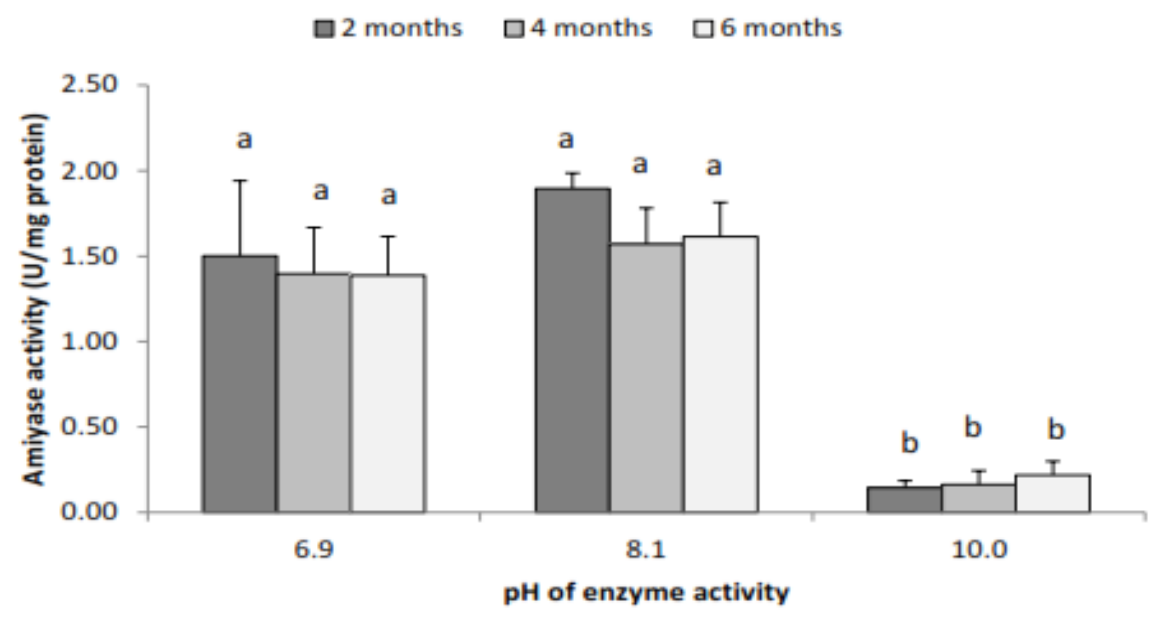

Figure 3. Amylase activity in Rasbora at different age. Means $(+\mathrm{sd})$ with different superscript letter are significantly different $(p<.05 ; \mathrm{n}=6)$.

The higher activity of lipase in a four month old fish than in two months old fish in this study, was in line with the decrease in protease activity. The phenomenon of a decrease in protease and increased lipase activity has been documented in fish that obtained intake of protein and high carbohydrate as occurred in Dentex dentex (Perez-Jimenez et al., 2009), Labeo brick (Mondal, Kaviraj, \& Mukhopadhyay, 2012) and Megalobrama amblycephala (Habte-Tsion et al., 2013).

There was no significant differences amylase activity between age of the fish (P>.05), but amylase activity was significantly influenced by the $\mathrm{pH}$ of incubation $(\mathrm{P}<.05)$ with the lowest activity at $\mathrm{pH} 10$ (Figure 3). In this study, the highest amylase activity was found at $\mathrm{pH} 6.9$ and 8.1, but it decreased at $\mathrm{pH}$ 10.0. The results of this study are lower than in previous studies on fish Betta splendens (Thongprajukaew et al., 2010) and Diplodus puntazzo (Savona et al., 2011). High amylase activity at neutral to slightly alkaline $\mathrm{pH}$, which reflects that the starch hydrolysis process occurs at a neutral to alkaline condition.

Amylase, that is active in such condition generally secreted by the pancreas or hepatopancreas and works in the area of intestine. Activities of amylase were dominant in the intestine with the alkaline condition has been documented in Odontobutis obscures (Ye et al., 2013), Lates niloticus (Namulawa et al., 2013), Etroplus suratensis and Oreochromis mossambicus (Sankar et al., 2014) and Tilapia rendali (Hlophe \& Moyo 2013). Differences in age of the fish in this study seem to also produce no significant difference of amylase activity, which indicates no change in the capacity of fish to digest complex carbohydrates, especially starch. A similar phenomenon occurred in fish that has no stomach as Hyporhamphus regularis ardelio (Day et al., 2011a), but different results were seen in Horabagrus brachysoma (Prasad \& Suneesha, 2013).

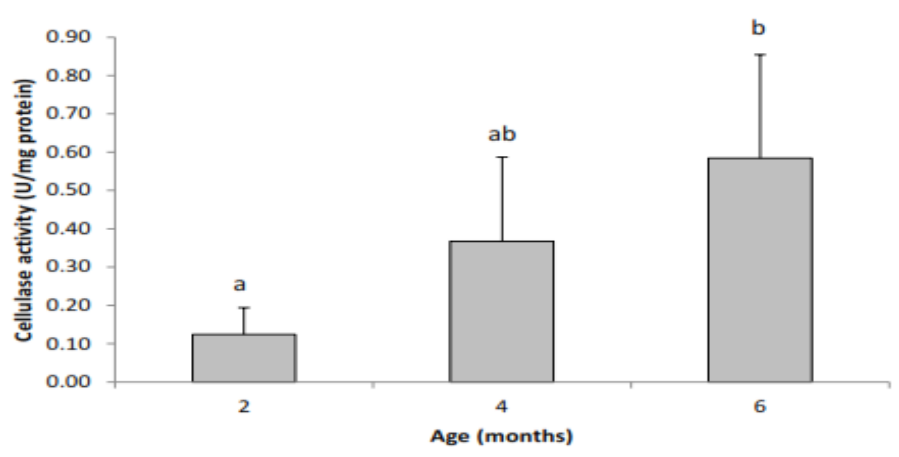

Figure 4. Cellulose activity in Rasbora at different age. Means (+sd) with different superscript letter are significantly different $(\mathrm{P}<.05 ; \mathrm{n}=6)$. 


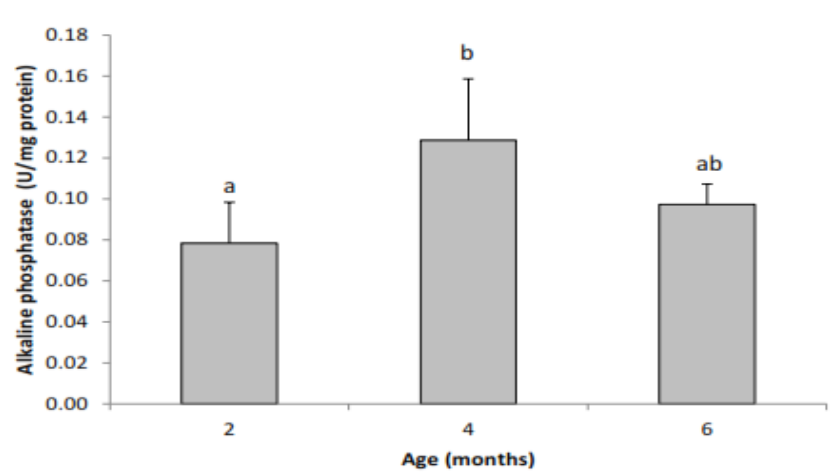

Figure 5. Alkaline phosphatase activity in Rasbora at different age. Means (+sd) with different superscript letter are significantly different $(\mathrm{P}<.05 ; \mathrm{n}=6)$

In this study the cellulose activity was significant differences between the ages of the fish $(\mathrm{P}<.05)$ and high activity in fish ages of four and six months (Figure 4). Cellulose activity changed with the increase age of the Rasbora. Six months old fish had higher cellulose activity than two months old fish, but did not differ from four months old fish. The results of this study indicated that Rasbora at six months age had higher ability to digest crude fiber than fish of two months age. Increased capacity to digest crude fiber of the fish indicated that in fish intestine, it is suspected that symbiotic microorganisms synthesize cellulose, because cellulose in the fish intestine derives from the secretions of the gut of microbes (Krogdahl, Hemre \& Mommsen, 2005; Kar \& Ghosh, 2008).

The activities of cellulose in the intestine of fish were also shown in previous studies on fish omnivore (Fagbenro et al., 2005; Tongsiri, Mang-Amphan \& Peerapornpisal, 2010; Savona et al., 2011). However, previous studies showed that cellulose activity was related to the composition of the feed in the digestive tract. Carnivorous fish that consumed macro algae had higher cellulose activity compare to fish that did not consume the macro algae (Chaudhuri, Mukherjee, \& Homechaudhuri, 2012).

Alkaline phosphatase activity showed a significant difference between the age of the fish $(\mathrm{P}<.05)$, and high alkaline phosphatase activity in fish age of four months (Figure 5), but it was not different with six months old fish. Increased activity of alkaline phosphatase in four month old fish in this study reflected the increase of nutrient absorption ability with decreasing the activity of protease and increasing lipase activity in Rasbora. The phenomenon of the increase of alkaline phosphatase activity with the increase in lipase activity, was documented in fingerling Mesopotamichthys sharpeyi (Rahimi, Sayed Mohammad \& Mohammad, 2015). Alkaline phosphatase is an enzyme involved in the breakdown of phosphate bonds so that it is easily absorbed in the substrate of proteins, lipids and carbohydrates, and the decrease in the intake of nutrients such as lipids can reduce its activity (Ducasse-Cabanot et al., 2007), and generally alkaline phosphatase works on the surface of intestine enterocytes microvillus (Minjoyo, Tan-Fermin, \& Macaranas 2003), so, the highest activity of alkaline phosphatase in larvae Rutilusfrisiikutum occur after microvillus is formed (Hassanatabar, Ouraji, Esmaelli \& Babaei, 2013).

\section{CONCLUSIONS}

Fish with two months of age had higher protein digestion than the older one, but the ability to digest carbohydrates, especially starch was not influenced by differences in age. The ability of Rasbora to digest fat and fiber increased with the increase age of the fish as well as feed absorption efficiency, improved with the increase of age reflected by the activity of alkaline phosphatase.

\section{ACKNOWLEDGEMENTS}

Thanks to the Indonesian Ministry of Research and Higher Education that has provided research funding through the Doctoral Dissertation Grant from the Ministry of Research, Technology and Higher Education in 2016 so that this research can be accomplished.

\section{REFERENCES}

Abdel-Tawwab, M., Ahmad, M.H., Kattab, Y.A.E. \& Shalaby, A.M.E., 2010. 
Effects of dietary protein levels, initial body weight, and their interaction on the growth, feed utilization, and physiological alterations of Nile tilapia, Oreochromis niloticus (L). Aquaculture, 298: 267-274. http://dx.doi.org/10.1016/j.aquaculture.2 009.10 .027

Abdel-Warith, A.A., Younis, E.M. \& Abdualla, A.N., 2013. Influence of dietary of full-fat soybean meal and amino acids supplementation on growth and digestive enzymes activity of nile tilapia, Oreochromis nilocitus. Turkish Journal of Fisheries and Aquatic Sciences, $\quad$ 13: 69-77. http://dx.doi.org/10.4194/1303-2712v13_1_09

Abidin, D.A.Z., Hashim, M., Das, S.K., Rahim, S.M., Mazlan A.G., 2016. Enzymatic digestion of stomachless fish Enarchopterus bufonis. AACL Bioflux, 9(3): 695-703.

Borlongan, I.G., 1990. Studies on the digestive lipases of milkfish, Chanos chanos. Aquaculture, $89\{$ 315-325.

Caruso G., Denaro M. G., Genovese L., 2009. Digestive enzymes in some teleost species of interest for Mediterranean aquaculture. The Open Fish Science Journal, 2: 74-86. http://dx.doi.org/10.2174/1874401X009 02010074

Chan, C.R., Lee, D.N., Cheng, Y.H., Hsieh, D.J.Y. \& Weng, C.F., 2008. Feed deprivation and re-feeding on alterations of proteases in tilapia Oreochromis mossambicus. Zoological Studies, 47 (2): 207-214.

Chaudhuri, A., Mukherjee, S. \& Homechaudhuri, S., 2012. Diet composition and digestive enzymes activity in carnivorous fishes inhabiting mudflats of Indian Sundarban Estuaries. Turkish Journal of Fisheries and Aquatic Sciences, 12: 265-275. http://dx.doi.org/10.4194/1303-2712v12_2_11

Day, R.D., German, D.P., Tibbetts, I.R., 2011a. Why can't young fish eat plant? Neither digestive enzymes nor gut development preclude herbivory in the young of a stomachless marine herbivorous fish. Comparative Biochemistry and Physiology, Part B.,
158:23-29.

http://dx.doi.org/10.1016/j.cbpb.2010.09 .010

Day, R.D., German, D.P., Manjakasy, J.M., Farr, I., Hansen, M.J. \& Tibbetts, I.R., 2011b. Enzymatic digestion in stomachles fishes: how a simple gut accommodates both herbivory and carnivory. Journal Comparative Physiology, Part B, 181:603-613. http://dx.doi.org/10.1007/s00360-0100546-y

Debnath, D., Pal, A.K., Sahu, N.P., Yengkokpam, S., Baruah, K., Choudhury, D. \& Venkateshwarlu G., 2007. Digestive enzymes and metabolic profile of Labeo rohita fingerlings fed diets with different crude protein levels. Comparative Biochemistry and Physiology, Part B, 146: 107-114. http://dx.doi.org/10.1016/j.cbpb.2006.09 .008

Ducasse-Cabanot, S., Zambonino-Infante, J., Richard, N., Medale, F., Corraze, G., Mambrini, M., Robin, J., Cahu, C., Kaushik, S. \& Panserat, S., 2007. Reduced lipid intake leads to changes in digestive enzymes in the intestine but has minor effects on key enzymes of hepatic intermediary metabolism in rainbow trout (Oncorhynchus mykiss). Animal, $\quad 1 \quad$ (9): $1272-1282$. http://dx.doi.org/10.1017/S17517311070 00596

Fagbenro, O., Adedire, O. Fateru, O., Owolabi, I., Ogunlana, O., Akanbi, B., Fasanmi, T. \& Ayo-Amu, P., 2005. Digestive enzyme assays in the gut of Oreochromis niloticus lines 1757, Parachanna (Channa) obscura Gunther 1861 and Gymnarchus niloticus Cuvier 1829. Animal Research International, 2(2): $292 \quad-\quad 296$. http://dx.doi.org/10.4314/ari.v2i2.40854

Falcon-Hidalgo, B., Forrellat-Barrios, A., Farnes, O.C., Hernandez, K.U., 2011. Digestive enzymes of two freshwater fishes (Limia vittata and Gambusia punctate) with different dietary preferences at three developmental stages. Comparative Biochemistry and Physiology, Part B, 158: 136-141. http://dx.doi.org/10.1016/j.cbpb.2010.10 .009 
Ganguly, S. \& Prasad, A., 2012. Microflora in fish digestive tract plays significant role in digestion and metabolism. Reviews in Fish Biology and Fisheries, 22: 11-16. http://dx.doi.org/10.1007/s11160-0119214-x

German, D.P., Horn, M. H. \& Gawlicka, A., 2004. Digestive enzyme activities in herbivorous and carnivorous prickleback fishes (Teleostei: Stichaeidae): Ontogenetic, Dietary and Phylogenetic effects. Physiological and Biochemical Zoology, 77(5): 789-804.

Habte-Tsion, H.M., Liu, B., Ge, X., Xie, J., Xu, P., Ren, M., Zhou, Q. Pan, L. \& Chen R., 2013. Effects of dietary protein level on growth performance, muscle composition, blood composition, and digestive enzyme activity of Wuchang bream (Megalobrama amblycephala) fry. The Israeli Journal of Aquaculture Bamidgeh, 1-9. http://www.siamb.org.il

Hassanatabar, F., Ouraji, H., Esmaeili, A., Babaei, S.S., 2013. Study of the activities of digestive enzymes, amylase and alkaline phosphatase, in kutum larvae, Rutilus frisiikutum fed artemia nauplii. World Journal of Fish and Marine Sciences, 5 (3): 266-270. http://dx.doi.org/10.5829/idosi.wjfms.20 13.05.03.66208

Hlope, S.N. \& Moyo, N.A.G., 2013. The aquaculture potential of Tilapia rendalli in relation to its feeding habits and digestive capabilities. Physics and Chemistry of the Earth, 66: 33-37. http://dx.doi.org/10.4194/1303-2712v12 211

Kamarudin, M.S., Otoi, S. \& Saad, C.R., 2011. Changes in growth, survival and digestive enzyme activities of Asian redtail catfish, Mystus nemurus, larva fed on different diets. African Journal of Biotechnology, 10 (21): 4484-4493. http://dx.doi.org/10.5897/AJB09.1895

Kar, N. \& Ghosh, K., 2008. Enzyme producing bacteria in the gastrointestinal tracts of Labeo rohita (Hamilton) and Channa punctatus (Bloch). Turkish Journal of Fisheries and Aquatic Sciences, 8:115120.

Kishimura, H., Klomklao, S., Benjakul, S. \& Chun, B.S., 2008. Characteristics of trypsin from the pyloric ceca of walleye Pollock (Theragra chalcogramma). Food Chemistry, 106: 194-199.

Klahan, R., Areechon, N., Yoonpundh, R. \& Engkagul, A., 2009. Characterization and activity of digestive enzymes in different sizes of nile tilapia (Oreochromis niloticus L.). Kasetsart J. (Nat. Sci.), 43: 143 - 153.

Kottelat, M., Whitten, A.J., Kartikasari, S.N. \& Wirjoatmodjo, S., 1993. Freshwater Fishes of Western Indonesia and Sulawesi. Jakarta : Periplus Edition Limited. pp: 60-66

Krogdahl, A., Hemre, G.I. \& Mommsen T.P., 2005. Carbohydrates in fish nutrition: digestion and absorption in postlarval stages. Aquaculture Nutrition, 11(2): 103-122.

http://dx.doi.org/10.1111/j.13652095.2004.00327.x

Kumar, S., Gracia-Carreno, F.L., Chakrabarti, R., Toro, M.A.N. \& Cordova-Murueta, J.H., 2007. Digestive protease of three carps Catla catla, Labeo rohita and Hypophthalmichthys molitrix : Partial characterization and protein hydrolysis efficiency. Aquaculture Nutrition, 13: 381-388. http://dx.doi.org/10.1111/j.13652095.2007.00488.x

Langeland, M., Lindberg, J.E. \& Lundh T., 2013. Digestive enzyme activity in Eurasian perch (Perca fluviatilis) and artic charr (Salvelinus alpinus). Aquaculture Research and Development, 5 (1): $1-8$. http://dx.doi.org/10.4172/21559546.1000208

Lazzari, R., Neto,J.R., Pedron, F.A., Loro, V.L., Pretto, A.\&Gioda, C.R., 2010. Protein sources and digestive enzyme activities in jundia (Rhamdia quelen). Sci. Agric. (Piracicaba, Braz.), 67(3): 259-266.

Liu, W., Zhang, X. \& Wang, L., 2010. Digestive enzyme and alkaline phosphatase activities during the early stages of Silurus soldatovi development. Zoological Research, 31 (6): 627-632. http://dx.doi.org/10.3724/SP.J.1141.201 0.06627

Maity, J., Kundu, J., Pramanik, A. \& Patra, B.C., 2011. Effect of cellulolytic gut bacteria as a feed supplement on the growth performance and nutrient 
digestibility of Asian seabass (Lates calcarifer). International Journal of Aquatic Science, 2 (1): 3-15.

Minjoyo, H., Tan-Fermin, J.D. \& Macaranas, J.M., 2003. Localization of enzymes in the digestive tract during the larval to early juvenile stages of sea bass (Lates calcarifer Bloch). Indonesian Fisheries Research Journal, 9(1): 46-53.

Mondal, K., Kaviraj, A. \& Mukhopadhyay, P.K., 2012. Effects of partial replacement of fishmeal in the diet by mulberry leaf meal on growth performance and digestive enzyme activities of Indian minor carp Labeo bata. International Journal of Aquatic Science, 3(1): 72-83.

Muchlisin, Z.A., Musman, M., and Azizah, M.N.S., $\quad 2010 . \quad$ Length-weight relationships and condition factors of two threatened fishes, Rasbora tawarensis and Poropuntius tawarensis, endemic to Lake Laut Tawar, Aceh Province, Indonesia. Journal of Applied Ichthyology, $\quad 26: \quad 949-953$. http://dx.doi.org/10.1111/j.14390426.2010.01524.x

Muchlisin Z.A., Musman, M., Fadli, N. and Azizah, M.N.S., 2011. Fecundity and spawning frequency of Rasbora tawarensis (Pisces : Cyprinidae) and endemic spesies from Lake Laut Tawar, Aceh, Indonesia. AACL Bioflux, 4(3): 273-279.

Namulawa, V.T., Kato, C.D., Rutaisire, J., Britz, P.J., Beukes, N., Pletschke, B.I. \& Whiteley, C., 2013. Enzyme activity in the Nile perch gut: Implications to Nile perch culture. International Journal of Fisheries and Aquaculture, 5 (9): 221228. http://dx.doi.org/10.5897/IJFA13.0349

Odedeyi, D.O. \& Fagbenro, O.A., 2010. Feeding habits and digestive enzymes in the gut of Mormyrus rume (Valenciennes 1846) (Osteichthyes Mormyridae). Tropical Zoology, 23: 7589.

Pena, E., Hernandez, C., Alvarez-Gonzalez , C.A., Ibarra-Castro, L., Puello-Cruz, A. \& Hardy, R.W., 2015. Comparative characterization of protease activity in cultured spotted rose snapper juveniles (Lutjanus guttatus). Latin American Journal of Aquatic Research, 43 (4):
641-650.

http://dx.doi.org/10.3856/vol43-issue4fulltext-3

Perez-Jimenez, A., Cardenete, G., Morales, A.E., Garcia-Alcazar, A., Abellan, E. \& Hidalgo, M.C., 2009. Digestive enzymatic profile of Dentex dentex and response to different dietary formulations. Comparative Biochemistry and Physiology, Part A, 154: 157-164. http://dx.doi.org/10.1016/j.cbpa.2009.05 .126

Prasad, G. \& Suneesha, I. 2013. Digestive enzyme characterization of threatened yellow catfish Horabagrus brachysoma (Gunther) (Teleotes : Siluriformes: Horabragridae) at two life stages. Journal of Aquatic Biology \& Fisheries, 1(1\&2): 83-89.

Rahimi, Y.N., Sayed Mohammad, Z.N.M. \& Mohammad, Z., 2015. Effects of ginger (Zingiber officinale) extract on digestive enzymes and liver activity of Mesopotamichthys sharpeyi fingerlings. Journal of Persian Golf, 6(19): 1-10.

Rosadi, E., Yuli, H.E., Setyohadi, D. \& Bintoro, G., 2014. Distribution, composition and abiotic enviroment of silver Rasbora (Rasbora argyrotaenia Blkr.) fish in upstream areas of Barito watershed, South Kalimantan. Journal of Enviroment and Ecology, 5(1): 117126.

http://dx.doi.org/10.5296/jee.v5i1.5880

Rungruangsak-Torrissen, K., Stien, L.H., Daae, B.S., Vågseth, T., Thorsheim, G.B., Tobin, D. \& Ritola, O., 2009. Different Dietary Levels of Protein to Lipid Ratio Affected Digestive Efficiency, Skeletal Growth, and Muscle Protein in Rainbow Trout Families. Scholarly Research Exchange, Vol. 2009 (2009), Article ID 709529, 13 pages. http://dx.doi.org/10.3814/2009/709529

Sankar, H., Jose, J., Varadarajan, R., Bhanu, S.V., Joy, S. \& Philip, B., 2014. Functional zonation of different digestive enzymes in Etroplus suratensis and Oreochromis mossambicus. International Journal of Scientific and Research Publications, 4(5): 1-5.

Santigosa, E., Garcia-Meilan, I., Valentin, J.M., Perez-Sanchez, J., Medale, F., Kaushik, S., Gallardo, M.A., 2011. Modifications of intestinal nutrient 
absorption in response to dietary fish meal replacement by plant protein sources in sea bream (Sparus aurata) and rainbow trout (Onchorynchus mykiss). Aquaculture, 317: 146-154. http://dx.doi.org/10.1016/j.aquaculture.2 011.04 .026

Savona, B., Tramati, C. \& Mazzola, A., 2011. Digestive Enzymes in Larvae and Juveniles of Farmed Sharpsnout Seabream (Diplodus puntazzo) (Cetti, 1777). The Open Marine Biology Journal, 5: 47-57. http://dx.doi.org/10.2174/187445080110 $\underline{5010047}$

Silva, F.C.P., Nicoli, J.R., Zambonino-Infante, J.L., Marie-Madeleine, L.G., Kaushik, S., Gatesoupe, F.J., 2010. Influence of partial substitution of dietary fish meal on the activity of digestive enzymes in the intestinal brush border membrane of gilthead sea bream, Sparus aurata and goldfish, Carassius auratus. Aquaculture, 306: 233-237. http://dx.doi.org/10.1016/j.aquaculture.2 010.05 .018

Sulistiyarto, B., 2012. Length-weight relationship, condition factor, and food composition of Seluang (Rasbora argyrotaenia Blkr.) in Rungan River Flood Plain, Central Kalimantan. Jurnal Ilmu Hewani Tropika. Vol 1(2): 62-66

Susilo, U., Yuwono, E., Rachmawati, F.N., Priyanto, S. \& Hana, 2015. Characteristics of digestive enzymes, protease and amylase, of gourami (Osphronemus gouramy Lac.) in the growth phase. Biosfera, 32 (2): 134-142. http://dx.doi.org/10.20884/1.mib.2015.3 2.2.3050

Susilo, U., Sukardi, P. \& Affandi, R. 2016. Alkaline protease, amylase and cellulase activities of yellow rasbora, Rasbora lateristriata Blkr., at different feeding levels. Molekul, 11(2) : 190-201. http://dx.doi.org/10.20884/1.jm.2016.11. 2.254

Thongprajukaew, K., Kovitvadhi, U., Engkagul, A. \& RungruangsakTorrissen, K., 2010. Temperature and $\mathrm{pH}$ characteristics of amylase and lipase at different development stages of siamese fighting fish (Betta splendens Regan, 1910). Kasetsart Jornal (Nat. Sci.), 44: 210-219.
Thongprajukaew, K., Kovitvadhi, U., Kovitvadhi, S., Somsueb, P., Rungruangsak-Torrissen, K., 2011. Effects of different modified diets on growth, digestive enzyme activities and muscle compositions in juvenile Siamese fighting fish (Betta splendens Regan, 1910). Aquaculture, 322-323: 19.

http://dx.doi.org/10.1016/j.aquaculture.2 011.10.006

Thongprajukaew, K., \& Kovitvadhi, U., 2013. Effects of sex on characteristics and expression levels of digestive enzymes in the adult guppy, Poecilia reticulata. Zoological Studies, 52(3): 1-8.

Tongsiri, S., Mang-Amphan, K. \& Peerapornpisal, $\quad$ Y., 2010. Characterization of amylase, cellulase and proteinase enzyme in stomach and intestine of the mekong giant catfish fed with various diets consisting of Spirulina. Current Research Journal of Biological Sciences, 2 (4): 268-274.

Umalatha, S.N., Kushwaha, J.P. \& Gangadhar, B., 2016. Digestive enzyme activity in different size groups and segments of the digestive tract in Labeo rohita (Day, 1878). Journal of Aquaculture \& Marine Biology, $\quad 4(5): \quad 00098$. http://dx.doi.org/10.15406/jamb.2016.04 .00098

Wu, R., Hong, W. \& Zhang, Q., 2010. Digestive enzyme activities in mudskipper boleophthalmus pectinirostris and Chinese black sleeper Bostrichthys sinensis. Chinese Journal of Oceanology and Limnnology, 28(4): 756-761. http://dx.doi.org/10.1007/s00343-0109111-5

Xiong, D.M., Xie, C.X., Zhang, H.J. \& Liu, H.P., 2010. Digestive enzymes along digestive tract of a carnivorous fish Glyptosternum maculatum (Sisoridae, Siluriformes). Journal of Animal Physiology and Animal Nutrition, 95: 56-64. http://dx.doi.org/10.1111/j.14390396.2009.00984.x

Ye, J.S., Chen, X.J. \& Zhu, Y.Y. 2013. Influence of $\mathrm{pH}$ on survival, growth and activities of digestive enzymes of Odontobutis obscures. Advance Journal of Food Science and Technology, 5 (9): 1234-1237. 
Zambonino-Infante, J.L. \& Cahu, C.L., 2007. Dietary modulation of some digestive enzymes and metabolic processes in developing marine fish: Applications to diet formulation. Aquaculture ,268 (14): 98-105. http://dx.doi.org/10.1016/j.aquaculture.2 007.04 .032 